\title{
Corporate Social Responsibility Disclosures and Board Structure: Evidence from Malaysia
}

\author{
Shazrul Ekhmar Abdul Razaka, Mazlina Mustapha ${ }^{b^{*}}$ \\ aPutra Business School, Universiti Putra Malaysia, 43400 UPM, Serdang, Selangor, Malaysia \\ ${ }^{b}$ Faculty of Economics and Management, Universiti Putra Malaysia, 43400 UPM, Serdang, Selangor, Malaysia
}

*Corresponding author: mazlina05@gmail.com

Article history

Received :4 April 2013

Received in revised form : 25 July 2013

Accepted :15 October 2013

\begin{abstract}
Corporate governance is a critical element in driving excellence in corporate social responsibility (CSR). One of the important cornerstones of corporate governance is board of directors. Thus, this study attempts to examine the effect of this board structure on corporate social responsibility disclosures of public listed companies in Malaysia. Data for the study was collected using secondary source. CSR disclosure index was developed in an attempt to examine the CSR disclosure in the four dimensions as specified by the Bursa Malaysia. The four dimensions are environmental, community, workplace and marketplace. Multiple regression analysis was employed to analyze the data. The result shows that managerial ownership is significant and negatively influences the CSR disclosure in Malaysian listed companies. The other board variables appear to have the expected direction of the hypotheses, but are not significant.
\end{abstract}

Keywords: Corporate governance; corporate social responsibility; board structure; public listed companies; Malaysia

(C) 2013 Penerbit UTM Press. All rights reserved.

\subsection{INTRODUCTION}

Corporate social responsibility (CSR) has emerged as an important factor for most companies to be successful in business today. Engaging in CSR helps companies to improve financial performance, enhance brand image and reputation, increase the ability to attract and retain the best workplace, increase sales and customer loyalty and better investor relations and access capital (Said, Zainuddin and Haron, 2009; Luan, 2005). This is supported by Mahoney and Roberts (2007) who claim that CSR practices do not only improve financial performance but also attract positive responses from investors. It is claimed that investors perceive that corporate social information is as important as financial information, and they take social information into consideration in decision making processes (Abdullah, Mohamad and Mokhtar, 2011).

This indicates that the role of a business today is not restricted to profit making alone but also include an element of corporate social responsibility and accountability. CSR can be defined as "the commitment of business organizations to contribute to sustainable development, stakeholder issues/concerns and improvement of societal conditions" (Jamali, Hallal and Abdallah, 2010). It is also referred to as a mode of business engagement and value creation which fulfills legal, ethical and public societal expectations (Luetkenhorst, 2004). Although an exact definition of CSR remains elusive, the term is generally used to refer to an obligation by the firms to use their resources in a sustainable manner to benefit not just themselves but society at large (ACCA, 2006).

In Malaysian business fraternities, managers have begun to be concerned about CSR issues (Abdullah et al., 2011) and these issues have attracted much attention over the years. Saleh, Zulkifli and Muhamad (2011) argue that the awareness level of CSR among Malaysian managers is high but, unfortunately, this is not followed by CSR activities and disclosure. Managers' awareness on CSR issues should be reflected in the companies' annual report to reduce the gap between their stakeholders and legitimize their existence (Said et al., 2009). However, it is still unclear as to what really motivates Malaysian companies to disclose social and environmental information, given the high awareness among managers and public demand for related information.

According to Jamali et al., (2010), corporate governance and CSR are closely related as they reflect a firm's commitment to its internal stakeholders as well as to the environment and society at large. It is claimed that companies will not act responsibly if their corporate social responsibility issues are not integrated in their decision-making and governance structures. It is expected that effective corporate governance would ensure that the stakeholders' interest is looked after (Spitzeck, 2009).

Shahin and Zairi (2007) further claim that corporate governance is a critical element for driving excellence in CSR 
and suggest that organizations should examine their corporate governance capabilities towards CSR. It has also been suggested that companies with good governance, such as having appropriate board size, separation of CEO and chairman position and boards dominated by outsiders or non-executive directors (NEDs) may help to alleviate the agency problem by monitoring and controlling the opportunistic behavior of management (Jensen and Meckling, 1976) and increase the transparency of the organizations in disclosing their activities to the stakeholders. This is supported by Abdullah et al., (2011) who claim that good corporate governance should also promote corporate transparency and accountability to the shareholders and the society.

Thus, this study attempts to investigate how the corporate governance structure namely, board size, board independence, CEO duality and managerial ownership influence the CSR disclosure in a developing country, particularly in Malaysia.

This paper is organized as follows. Section 2 provides literature review and the development of the research hypotheses. Research methodology comprising data collection, sampling design and measurement of variables are presented in Section 3. Next, results and discussion are explained in Section 4. Finally, conclusion, limitation and suggestion for further research are provided in Section 5.

\subsection{LITERATURE REVIEW AND HYPOTHESES DEVELOPMENT}

Corporate governance is a set of control mechanisms designed to monitor and check the management's decisions on behalf of the stakeholders. Corporate management which is led by the board of directors may reduce the information disclosed in order to conceal the real economic performance of the organizations from its stakeholders. Thus, the role of corporate governance, especially the board of directors in this information asymmetry problem is crucial (Donnelly and Mulcahy, 2008; Said et al., 2009). There is a greater social expectation which demand organizations to react and attend human, environmental and other social consequences (Heard and Bolce, 1981). Thus, this paper examines the monitoring role played by the board and their ownership structure in relation to CSR.

\subsection{Board Independence And CSR Disclosure}

It is expected that the existence of independent directors on corporate boards would result in more effective monitoring of the board and limit managerial opportunism (Fama and Jensen, 1983; Mohd Ghazali and Weetman, 2006). This is supported by Rosenstein and Wyatt (1990), who posit that independent directors are perceived as a tool for monitoring the management's behavior resulting in more voluntary disclosure of corporate information.

As outlined by Malaysian Code on Corporate Governance (MCCG, 2007), independent director is a person who can bring a broader view to the company's activities. Thus, their existence would lead to more voluntary disclosure of corporate information (Said et al., 2009) as they are expected to be willing to meet the information demands of other stakeholders (Abdullah et al., 2011).

Adams and Hossain (1998) report a significant positive association between voluntary disclosure and the proportion of independent directors on the board. Further, inclusion of the independent directors on corporate boards improves the comprehensiveness and quality of disclosure (Akhtaruddin,
Hossain, Hossain and Yao, 2009; Forker, 1992; Chen and Janggi, 2001). Thus, it is hypothesized that:

$\mathrm{H}_{1}$ : There is a positive relationship between the proportion of board independence and CSR disclosure.

\subsection{CEO Duality And CSR Disclosure}

CEO duality occurs when the same person holds both the CEO and the chairman position in a company (Rechner and Dalton, 1989; Mohamad \& Sulong, 2010). It is argued that companies that have CEO duality disclose less detail information in annual reports (Forker, 1992) because a person who has combined roles would withhold unfavorable information to other stakeholders (Mohamad and Sulong, 2010).

In Malaysia, MCCG 2007 recommends the separation roles of the chairman and CEO and a decision to combine these two roles should be publicly explained. It is expected that independence of the Chairman would lead to a more transparent board and greater disclosure (Mohd Ghazali and Weetman, 2006). Mohamad and Sulong (2010) report a positive relationship between the practice of separate CEO and Chairman with the level of disclosure. Thus it is hypothesized that:

$\mathrm{H}_{2}$ : There is a negative relationship between CEO Duality and CSR disclosure.

\subsection{Board Size And CSR Disclosure}

It is expected that board size may influence the level of disclosure in companies' annual report. Chen and Janggi (2001) argue that a company can reduce information asymmetry between its managers and other stakeholders by having a greater number of directors sitting on the board. Board of directors is one of the most important elements of corporate governance mechanism in overseeing the conduct of a company's business and ensures that it is being properly managed by their agents (Said et al., 2009).

It is believed that the size of the board will affect the ability of the board to monitor and evaluate the management (Akhtaruddin et al., 2009; Zahra, Neubaum and Huse, 2000). Abdullah et al., (2011) claim that board size can influence the level of voluntary and social disclosure (Abdullah et al., 2011). Akhtaruddin et al., (2009) state that with more directors, the collective experience and expertise of the board will increase, and therefore, the need for the disclosure will be higher. Thus, it is hypothesized that:

$\mathrm{H}_{3}$ : There is a positive relationship between board size and CSR disclosure.

\subsection{Managerial Ownership And CSR Disclosure}

Janggu, Joseph and Madi, (2007) claim that company's ownership structure will affect its reporting strategy. Publicowned companies face greater pressure to disclose additional information in their annual report, particularly the companies' CSR activities. Ironically, owner-managed companies are common in Malaysia (Mohd Ghazali and Weetman, 2006) as majority of the listed companies in Malaysia started off as family businesses. Hence, the board is usually dominated by family members and the CEO is also from the family itself (Abdullah et al., 2011). It is claimed that owner-managed companies may be less involved in social activities because outsiders' interest may be relatively small, and they perceive 
that the costs of investing in these activities may far outweigh their potential benefits (Mohd Ghazali, 2007).

This is supported by prior studies by Guan Yeik (2006) and Eng and Mak (2003) which examine the relationship between managerial ownership and CSR disclosure. Guan Yeik (2006) reports that there is a negative significant relationship between managerial ownership and CSR disclosure in Malaysian public listed companies. Abdullah et al., (2011) also find that ownermanaged companies are negatively associated with the extent and quality of CSR disclosure. Mohd Ghazali, (2007) reports that companies which have higher portion of executive directors shares disclose less CSR information (Mohd Ghazali, 2007). In addition, Eng and Mak (2003) find that lower managerial ownership is associated with increased voluntary disclosure in Singaporean listed companies. Hence, it is hypothesized that:

$\mathrm{H}_{4}$ : There is a negative relationship between managerial ownership and CSR disclosure.

\subsection{RESEARCH METHODOLOGY}

Data and sample size which is used in this paper and the measurement of CSR disclosure as well as regression model and definition of variables are described in this section.

\subsection{Data Collection}

In order to achieve the objective of the study, the data is collected from the annual reports of Malaysian listed companies for the year ended 2010. Annual reports are the main source of the data as used in prior studies (Abdullah et al., 2011; Said et al., 2009; Amran and Susela, 2009; Haniffa and Cooke, 2005; Hackstone and Milne, 1996). Annual reports are used as they are regarded as the main form of company communication (Amran and Susela, 2008), and considered as a major source of information to the shareholders (Nik Ahmad and Sulaiman, 2004). In addition, annual report is readily available and easily accessible (Saleh et al., 2011; Uwuigbe, 2011).

\subsection{Sampling Design}

The population of this study comprises of all companies listed on the main board of Bursa Malaysia as at 31 December 2010. As at that date, there were 844 companies listed on the main board, including 38 of finance companies and 35 of PN17 companies. For the purpose of this study, companies classified under finance sector and PN17 were excluded because of differences in their compliance and regulatory requirements as well as their unique features and business activities (Yatim, Kent and Clarkson, 2006). A total of 200 companies were randomly selected. This represents 25.94 percent of the total population. This sample size fulfils the minimum sample size requirement as proposed by Krejcie and Morgan (1970).

Stratified random sampling method was used to determine the sample size of each sector. This sampling technique was used to ensure that representative sample from all sectors were selected as used by prior studies (Othman and Ishak, 2011; Amran and Susela, 2008; Said et al., 2009). Table I presents the selected companies by sectors.
Table 1 sample and population for each sector

\begin{tabular}{|c|c|c|c|c|}
\hline \multirow[b]{2}{*}{ Sector } & \multicolumn{2}{|c|}{ Main board } & \multirow[b]{2}{*}{$\begin{array}{c}\text { Total } \\
\text { sample }\end{array}$} & \multirow[b]{2}{*}{$\%$} \\
\hline & $\begin{array}{c}\text { Total } \\
\text { Population }\end{array}$ & $\%$ & & \\
\hline Consumer & 137 & 18 & 36 & 18 \\
\hline Industrial & 254 & 33 & 66 & 33 \\
\hline Construction & 43 & 6 & 11 & 6 \\
\hline Trading & 169 & 22 & 44 & 22 \\
\hline Infrastructure & 7 & 1 & 2 & 1 \\
\hline Technology & 30 & 4 & 8 & 4 \\
\hline Hotels & 4 & 0 & 1 & 0 \\
\hline Properties & 86 & 11 & 22 & 11 \\
\hline Plantation & 40 & 5 & 10 & 5 \\
\hline Mining & 1 & 0 & 0 & 0 \\
\hline Total & 771 & 100 & 200 & 100 \\
\hline
\end{tabular}

\subsection{Content Analysis and Disclosure Index}

The data collected in this study uses content analysis and a disclosure index is developed. Content analysis approach has been widely used in corporate social reporting research (Guthrie and Parker, 1990; Haniffa and Cooke, 2005; Hackstone and Milne, 1996; Mohd Ghazali, 2007; Abdullah et al., 2011; Said et al., 2009). Content analysis is "a method of codifying the text (or content) of a piece of writing or categories depending on selected criteria" (Haniffa and Cooke, 2005).

According to Raman (2006), content analysis employs a three-step process. The three steps include choosing an appropriate document or unit of analysis and unit of measuring content, measuring the contents and identifying the themes or categories into which the content can be classified. For the purpose of this study, unit of analysis is the annual reports of companies listed on the main board of Bursa Malaysia. The themes, as classified by Bursa Malaysia, are environmental, community, workplace and marketplace. However, unit of measuring content is slightly different whereby this study decided to use CSR disclosure index because of considerable debates on the use of number of pages, words and sentences (Milne and Adler, 1999; Unerman, 2000; Amran and Susela, 2008; Azim, Ahmed and Islam, 2009).

In developing the index, references was first made to the items/checklists employed by previous research, particularly those conducted in Malaysia (Mohd Ghazali, 2007). The items 
were chosen based on past studies (Haniffa and Cooke, 2005; Hackstone and Milne, 1996; Salleh and Mustapha, 2005; Abdullah et al., 2011; Janggu et al., 2007; Yao, Wang and Song, 2011) which cover the four themes. The CSR disclosure items were extracted from companies' annual reports. Then CSR disclosure index was calculated by combining all items covering the four themes, which were environment, community, workplace and marketplace. The final list comprises of 40 items, 10 items for each theme. A dichotomous procedure is applied where a company is awarded 1 if an item included in the index is disclosed in the annual report and 0 if it is not disclosed. Accordingly, the CSR disclosure index for a company is derived by computing the ratio of actual scores awarded divided by the maximum score (40).

\subsection{Measurement of Variables and the Regression Model}

The dependent variable in this study is level of corporate social reporting disclosure. It is measured using content analysis (as explained in Section 3.3). The independent variables are board structure variables namely, board independence, CEO duality, board size and managerial ownership. In addition, the model has three control variables - firm's size, gearing and company sectors. These control variables are used to enhance the relationship between board structure variables and CSR disclosure.

Multiple regression analysis was used to examine the relationship between CSR disclosure and the independent variables. The following regression model is used in this paper:

$\mathrm{CSRD}=\beta_{0}+\beta_{1} \mathrm{BIND}+\beta_{2} \mathrm{DUAL}+\beta_{3} \mathrm{BSIZE}+\beta_{4} \mathrm{MOWN}+$ $\beta_{5}$ GEAR $+\beta_{6}$ SECTOR $1+\beta_{7}$ SECTOR $2+\varepsilon$

Where:

- CSRD = Corporate Social Reporting Disclosure,

- BIND = percentage of non-executive directors to total directors,

- DUAL = CEO Duality (Dummy variable: $1=$ if the CEO is also the Chairman of the board, and $0=$ otherwise),

- BSIZE = numbers of directors on the board,

- MOWN = percentage of shares owned by executive directors to total number of shares issued,

- SIZE = total assets $(\log )$,

- GEAR = Total long-term debt to total equity,

- $\quad$ SECTOR1 = Company sector, "1" for Consumer company or " 0 " otherwise,

- $\quad$ SECTOR 2 = Company sector, " 1 " for Industrial company or " 0 " otherwise,

- $\varepsilon=$ Error term

Correlation matrix and variance inflation factors were reviewed in order to check if the data has multicollinearity problem. Normality of the data is also checked to ensure the appropriateness of the regression model, and whether multiple regression assumptions have been violated.

\subsection{RESULTS AND DISCUSSION}

\subsection{Descriptive Statistics}

Table 2 shows the descriptive statistics for all variables in this study. The mean for the CSR disclosure is 39 per cent indicating an average of 15 items (out of 40 items in the disclosure index). The maximum disclosure level is 88 per cent or 35 items (out of
40 items in the disclosure index) and the minimum disclosure level is 5 per cent or 2 items (out of 40 items in the disclosure index). Similar studies on CSR research in Malaysia conducted by Mohd Ghazali (2007) and Abdullah et al., (2011) report CSR disclosure mean of $25.5 \%$ and $28 \%$ respectively. This indicates that, compared to these two results, CSR disclosure in Malaysia is increasing over the years, implying that more Malaysian managers are aware of the importance of CSR disclosure.

The mean percentage of shareholdings by the managers is about $9 \%$. All the sample companies have board of directors with their size ranging from 4 to 15 directors. This finding is similar to Yatim et al. (2006)'s study who find the board size range from 3 to 16 . The average board size of the sample companies is 7.51, which is the same as Yatim et al. (2006) of 7.51 , slightly lower than another studies on Malaysian data by Haniffa \& Hudaib (2006) and Mat Nor \& Sulong (2007) of eight. The results of standard tests of skewness and kurtosis indicate that there is no problem with normality assumption ${ }^{1}$. Thus, these variables can reasonably be considered as normally distributed. 
Table 2 Descriptive statistics for all variables

\begin{tabular}{|c|c|c|c|c|c|c|c|c|c|}
\hline & CSRD & BIND & DUAL & BSIZE & MOWN & SIZE & GEAR & SECTOR1 & SECTOR2 \\
\hline Mean & 0.39 & 0.46 & 0.18 & 7.51 & 0.09 & 8.78 & 0.31 & 0.18 & 0.33 \\
\hline Minimum & 0.05 & 0.22 & 0 & 4 & 0.00 & 7.481 & 0.00 & 0.00 & 0.00 \\
\hline Maximum & 0.88 & 0.88 & 1 & 15 & 0.72 & 10.87 & 3.30 & 1.00 & 1.00 \\
\hline Std. Dev & 0.19 & 0.13 & 0.39 & 1.92 & 0.15 & 0.71 & 0.46 & 0.39 & 0.47 \\
\hline Skewness & 0.64 & 074 & 1.678 & .889 & 1.99 & .643 & 3.42 & 1.67 & 0.73 \\
\hline Kurtosis & 0.10 & 0.02 & 0.86 & 1.102 & 3.63 & 0.62 & 15.21 & 0.86 & 1.48 \\
\hline
\end{tabular}

Table 3 Correlation analysis

\begin{tabular}{|c|c|c|c|c|c|c|c|c|c|}
\hline & CSRD & BIND & DUAL & BSIZE & MOWN & SIZE & GEAR & SECTOR1 & SECTOR2 \\
\hline CSRD & 1 & & & & & & & & \\
\hline BIND & 0.048 & 1 & & & & & & & \\
\hline DUAL & -0.073 & 0.057 & 1 & & & & & & \\
\hline BSIZE & $.211^{* *}$ & $.295^{* *}$ & 0.084 & 1 & & & & & \\
\hline MOWN & $-.227^{* *}$ & -0.04 & 0.011 & -0.096 & 1 & & & & \\
\hline SIZE & $.368^{* *}$ & 0.032 & -0.041 & $.477^{* *}$ & $-.295^{* *}$ & 1 & & & \\
\hline GEAR & 0.091 & -0.02 & -0.056 & $.192^{* *}$ & -0.064 & $.374^{* *}$ & 1 & & \\
\hline SECTOR1 & 0.023 & -0.06 & -0.05 & -0.036 & 0.093 & $-.200^{* *}$ & -0.117 & 1 & \\
\hline SECTOR2 & -0.03 & 0.06 & 0.031 & $-.187^{* *}$ & -0.049 & $-.205^{* *}$ & -0.025 & $-.329^{* *}$ & 1 \\
\hline
\end{tabular}

\subsection{Correlation Analysis}

Table 3 presents correlation analysis between dependent variable, independent variables and control variables. The results indicate that there is no multicollinearity problem, as the correlations among the independent variables are below the threshold value of 0.8 or 0.9 (Gujarati, 2003, p. 359). The correlations between independent variables in this study range between 0.011 to 0.477 which is less than 0.8 or 0.9 . To support this result, variance inflation factors (VIF) is checked. Pallant (2010) suggests that multicollinearity exists when VIF value is more than 10. The VIF values for this study range between 1.013 to 1.789 . Thus, VIF statistics appear to indicate that there is no multicollinearity problem.

\subsection{Regression Analysis}

Table IV reports the results of the multiple regression analysis in this study. The result in Table 4 indicates that the adjusted $\mathrm{R}$ squared for the model used in the study is 0.143 and the F-value is $5.144(\mathrm{p}<0.000)$. It means that more than $14 \%$ of the variation in the corporate social responsibility disclosure can be explained by the model. This Adjusted R squared is slightly higher than similar studies done by Abdullah et al., (2011) and Said et al., (2009) which report adjusted R Squared of 14\% and $13 \%$ respectively.

The result in Table 4 shows that managerial ownership has negative and significant relationship with CSR disclosure. Thus Hypothesis $\mathrm{H}_{4}$ is supported. This negative relationship appears to suggest that the higher the percentage of shares held by the board of directors, the lower is its CSR disclosure. This result is consistent with the findings from earlier studies by Mohd Ghazali (2007) and Akhtaruddin and Haron (2010). They claim that this negative relationship is due to the fact that ownermanaged companies are generally closely held and public accountability is less of an issue to them (Mohd Ghazali, 2007). And this may be more pronounced in Malaysian business environment where this ownership structure is more common, especially in family owned companies (Mohd Ghazali and Weetman, 2006). This type of companies may not invest heavily in socially responsible activities as the costs of investing in these activities may far outweigh its potential benefits (Mohd Ghazali, 2007), hence lead to lower level of CSR disclosure. This finding is also supported by Eng and Mak (2003) who find 
an inverse relationship between managerial ownership and voluntary disclosure.

Table 4 Regression analysis results

\begin{tabular}{|c|c|c|c|c|c|c|c|}
\hline \multirow{2}{*}{ Model } & \multicolumn{2}{|c|}{ Unstandardized Coefficients } & $\begin{array}{l}\text { Standardized } \\
\text { Coefficients }\end{array}$ & \multirow{2}{*}{$\mathbf{T}$} & \multirow{2}{*}{ Sig. } & \multicolumn{2}{|c|}{ Collinearity Statistics } \\
\hline & $\mathbf{B}$ & Std. Error & Beta & & & Tolerance & VIF \\
\hline (Constant) & -0.521 & 0.19 & & -2.74 & 0.007 & & \\
\hline BIND & 0.084 & 0.101 & 0.058 & 0.825 & 0.41 & .871 & 1.148 \\
\hline DUAL & -0.026 & 0.032 & -0.053 & -0.8 & 0.425 & .987 & 1.013 \\
\hline BSIZE & 0.007 & 0.008 & 0.074 & 0.921 & 0.358 & .668 & 1.496 \\
\hline MOWN & -0.154 & 0.087 & -0.123 & -1.77 & $0.078 * *$ & .895 & 1.117 \\
\hline SIZE & 0.093 & 0.023 & 0.356 & 4.056 & $0.000^{*}$ & .559 & 1.789 \\
\hline GEAR & -0.019 & 0.029 & -0.048 & -0.68 & 0.500 & .851 & 1.176 \\
\hline SECTOR1 & 0.065 & 0.035 & 0.134 & 1.837 & $0.068^{* *}$ & .813 & 1.230 \\
\hline SECTOR2 & 0.037 & 0.029 & 0.092 & 1.255 & 0.211 & .798 & 1.253 \\
\hline$\overline{\mathrm{R}^{2}}$ & 0.177 & & & & & & \\
\hline $\begin{array}{l}\text { Adjusted } \mathrm{R}^{2} \\
\text { F-value } \\
\text { Significant }\end{array}$ & $\begin{array}{l}0.143 \\
5.144 \\
0.000\end{array}$ & & & & & & \\
\hline
\end{tabular}

Table 5 Summary of the hypotheses

\begin{tabular}{|c|c|c|c|}
\hline Hypotheses & $\begin{array}{l}\text { Expected } \\
\text { direction }\end{array}$ & Result of the study & Results \\
\hline $\begin{array}{l}\mathrm{H}_{1} \text { : There is positive relationship between proportion of board independence } \\
\text { and the extent of CSR disclosure }\end{array}$ & + & + (not significant) & Not supported \\
\hline $\mathrm{H}_{2}$ : There is negative relationship between CEO Duality and CSR disclosure & - & - $\quad$ (not significant) & Not supported \\
\hline $\mathrm{H}_{3}$ : There is positive relationship between board size and CSR disclosure & + & $+($ not significant $)$ & Not supported \\
\hline $\begin{array}{l}\mathrm{H}_{4} \text { : There is negative relationship between managerial ownership and CSR } \\
\text { disclosure }\end{array}$ & - & - $\quad$ (significant) & Supported \\
\hline
\end{tabular}

The results in Table 4 also indicate that the other three independent variables (board independence, CEO duality and board size) have the same direction as hypothesized, but are insignificant in their relationship with CSR disclosure. Thus $\mathrm{H}_{1}$ $\mathrm{H}_{2}$ and $\mathrm{H}_{3}$ are not supported. The results are summarized in Table V.

The results in Table 4 indicate that board size and CEO duality do not have significant influence on CSR disclosure. This result is consistent with an earlier study by Said et al., (2009) who reported that these variables have no significant relationship with the level of CSR disclosure. Similarly, the result indicates that board independence have positive impact on CSR disclosure but not significant. The result is not surprising as Said et al., (2009) and Abdullah et al., (2011) also find no significant association between board independence and the extent of CSR and the quality of CSR disclosure. Abdullah et al., (2011) posit that this insignificant result is due to the fact that the board independence plays insignificant roles in the decision of CSR disclosure in Malaysia as these independent directors are not effective in discharging their duties. This is supported by Abdullah (2004) in other related study, who claims that independent directors in Malaysia are not effective in protecting stakeholders' interest as they are chosen from those who are in the same circle as the firms' CEO.

With regard to control variables, firm's size is found to have significant relationship with CSR disclosure. This is consistent with local as well as overseas' studies, for example, Haniffa and Cooke (2005), Said et al., (2009), Mohd Ghazali (2007), Smith et al., (2007) and Hackstone and Milne (1996). Larger size companies are more likely to engage in social activities compared to small companies because they have resources to do so (Abdullah et al., 2011), are more visible in the public eyes and are under greater pressure to exhibit their social responsibility (Mohd Ghazali, 2007). For company's sector classification, companies which are categorized under consumer sector appear to disclose more information relating to corporate social responsibility compared to those in other sectors. This result could be due to the increasing awareness of 
consumer companies to disclose CSR information as it is believed that as they are widely consumed, they need to generate more social visibility (Branco and Rodrigues, 2008; Yao et al., 2011).

\subsection{CONCLUSION}

The purpose of this study is to examine corporate governance characteristics and their influence on corporate social responsibility disclosure in Malaysian public listed companies. These characteristics include board independence, CEO duality, board size and managerial ownership. CSR disclosure index was used to measure disclosure pertaining to CSR activities undertaken by 200 sample companies listed on the main board of Bursa Malaysia.

The statistical results show that higher managerial ownership is significantly associated with lower level of CSR disclosure of sample companies. However, board size, board independence and CEO duality do not have any significant influence on CSR disclosure. This paper contributes to the literature in explaining the CSR disclosure in an emerging market. It also provides evidence that board characteristics are important factors to be considered by the companies in relation to their CSR disclosure.

This paper has its limitations. Firstly, this study uses one year data only, hence it cannot be generalised to other periods. Further study may include a few years of data and examine a longitudinal effect of these variables on CSR disclosure. Secondly, the use of companies' annual report may not give a complete picture of CSR disclosure practices as the companies may use other medium to disclose their CSR information. Future study should extend the scope of investigation on CSR disclosure by including standalone report, companies' website and business magazines

\section{References}

[1] Abdullah, S. N., Mohamad, R. and Mokhtar, M. Z. 2011. Board Independence, Ownership and CSR of Malaysia Large Firms. Faculty of Management and Economics. University of Malaysia Terangganu.

[2] ACCA Malaysia. 2006. Corporate social reporting: Making Business Sense in Malaysia, Accountant Today: Management \& Accounting. May Edition. 26-29.

[3] Adam, M. and Hossain, M. 1998. Managerial Discretion and Voluntary Disclosure: Evidence from the New Zealand Lifeinsurance Industry. Journal of Accounting and Public Policy. 17: 245-281.

[4] Akhtaruddin, M., and Haron, H. 2010. Board Ownership, Audit Committees' Effectiveness, and Corporate Voluntary Disclosures. Asian Review of Accounting. 18(3): 245-259.

[5] Akhtaruddin, M., Hossain, M. A., Hossain, M., and Yao, L. 2009 Corporate Governance And Voluntary Disclosure I Corporate Annual Reports of Malaysian Listed Firms. Journal of Applied Management Accounting Research. 7(1): 119.

[6] Amran, A., and Susela, S. D. 2008. The Impact of Government and Foreign Affiliate Influence on Corporate Social Reporting: The Case of Malaysia. Managerial Auditing Journal. 23(4): 386-404.

[7] Azim, M. I., Ahmed, S. and Islam, M. S. 2009. Corporate Social Reporting Practice: Evidence from Listed Companies in Bangladesh Journal of Asia-Pacific Business. 10(2): 130-145.

[8] Branco, M. C. and Rodrigues, L. L. 2008. Factors Influencing the Quality of Corporate Environmental Disclosure. Business Strategy and the Environment. 17(2): 120-136.

[9] Chen, C. J., and Jaggi, B. 2001. Association Between Independent Non-Executive Directors, Family Control and Financial Disclosures in Hong Kong. Journal of Accounting and Public Policy. 19(4): 285-310.

[10] Donnelly, R. and Mulcahy, M. 2008. Board Structure, Ownership and Voluntary Disclosure In Ireland, Corporate governance. 16(5): 416426.
[11] Eng. L. L and Mak, Y. T. 2003. Corporate Governance and Voluntary Disclosure. Journal of Accounting and Public Policy. 22(4): 325-345.

[12] Fama, E. F., and Jensen, M. C. 1983. Separation of Ownership and Control. Journal of Law and Economics. 26: 301-325.

[13] Forker, J. J. 1992. Corporate Governance and Disclosure Quality. Accounting and Business Research. 22(86): 111-124.

[14] Guan Yeik, T. 2006. The Relationship Between Board of Directors and Corporate Social Responsibility: Study on Malaysian Public Listed Companies, Master's in Accounting, Universiti Sains Malaysia, Penang, unpublished thesis.

[15] Gujarati, D. N. 2003. Basic Econometrics. 4th ed. Singapore: McGraw Hill.

[16] Guthrie, J. E., and Parker, L. D. 1990. Corporate Social Disclosure Practice: A Comparative International Analysis. Advances in Public Interest Accounting. 3(2): 159-176.

[17] Haniffa, R. M. and Cooke, T. E. 2005. The Impact of Culture and Governance on Corporate Social Reporting. Journal of Accounting and Public Policy. 24(5): 391-430.

[18] Haniffa, R. M. and Hudaib, M. 2006. Corporate Governance Structure and Performance of Malaysian Listed Companies. Journal of Business Finance \& Accounting. 33(7): 1034-1062

[19] Hackston, D. and Milne, M. J. 1996. Some Determinants of Social and Environmental Disclosures in New Zealand Companies. Accounting, Auditing \& Accountability Journal. 9(1): 77-108.

[20] Heard, J. E., and Bolce, W. J. 1981. The Political Significance of Corporate Social Reporting in The United States of America. Accounting, Organizations and Society. 6(3): 247-254.

[21] Ho, S. S., and Wong, K. S. 2001. A Study of the Relationship Between Corporate Governance Structures and the Extent of Voluntary Disclosure. Journal of International Accounting, Auditing and Taxation. 10(2): 139-156.

[22] Jamali, D., Hallal, M. and Abdallah, H. 2010. Corporate Governance and Corporate Social Responsibility: Evidence from theHealthcare Sector. Corporate Governance. 10(5): 590-602.

[23] Janggu, T., Joseph, C., and Madi, N. 2007. The Current State of Corporate Social Responsibility Among Industrial Companies in Malaysia. Social Responsibility Journal. 3(3): 9-18.

[24] Jensen, M. C., and Meckling, W. H. 1976. Theory of the Firms: Managerial Behaviour, Agency Costs and Ownership Structure. Journal of Financial Economics. 3: 305-360.

[25] Krejcie, R. V., and Morgan, D. W. 1970. Determining Sample Size for Research Activities. Educational and Psychological Measurement. 30: 607-610.

[26] Luan, T. K. 2005. CSR Challenges \& Trends in Corporate Malaysia, Accountant Today, Management \& Accounting. January \& February Edition: 40-43.

[27] Luetkenhorst, W. 2004. Corporate Social Responsibility and the Development Agenda. Intereconomics. 39(3): 157-168.

[28] Malaysian Code on Corporate Governance. 2007. Kuala Lumpur: Malaysian Law Journal Sdn Bhd.

[29] Mat Nor, F., \& Sulong, Z. 2007. The Interaction Effect of Ownership Structure and Board Governance on Dividends: Evidence from Malaysian Listed Firms. Capital Market Review. 15(1\&2): 73-101.

[30] Mohamad, W. I. W. and Sulong, Z. 2010. Corporate g Governance Mechanism and Extent of Disclosure: Evidence from Listed Companies in Malaysia. International Business Research. 3(4): 216-228.

[31] Mohd Ghazali, N. A. and Weetman, P. 2006. Perpetuating Traditional Influences: Voluntary Disclosure in Malaysia Following the Economic Crisis. Journal of International Accounting, Auditing and Taxation. 15 226-248

[32] Mahoney, L. and Roberts, R. W. 2007. Corporate Social Performance, Financial Performance and Institutional Ownership in Canadian Firms. Accounting Forum. 31(3): 233-253.

[33] Milne, M. J., and Adler, R. W. 1999. Exploring the Reliability of social and Environ-Mental Disclosures Content Analysis. Accounting, Auditing and Accountability Journal. 12(2): 237-256.

[34] Naser, K., Al-Hussaini, A., Al-Kwari, D., and Nuseibeh, R. 2006. Determinants of Corporate Social Disclosure in Developing Countries: the Case of Qatar. Advances in International Accounting. 19: 1-23.

[35] Nik Ahmad, N. N. and Sulaiman, M. 2004. Environmental disclosures in Malaysian Annual Reports: A Legitimacy Perspective. International Journal of Commerce and Management. 14(1): 44-58.

[36] Othman, N., and Ishak, S. 2011. Kecenderungan Terhadap Pemilihan Kerjaya Keusahawanan Mengikut Persepsi Peserta Skim Usahawan Siswa. Jurnal Teknologi. 56(1): 47-63.

[37] Pallant, J. 2010. SPSS Survival Manual: A Step by Step Guide to Data Analysis Using the SPSS Program. $4^{\mathrm{TH}}$ Edition. McGraw Hill Education. 
[38] Patten, D. M. 1992. Exposure, Legitimacy, and Social Disclosure. Journal of Accounting And Public Policy. 10(4): 297-308.

[39] Raman, S. R. 2006. Corporate Social Reporting in India-A View From the Top. Global Business Review. 7: 313-324.

[40] Rechner, P. L., and Dalton, D. R. 1989. The Impact of CEO as Board Chairperson on Corporate Performance: Evidence Vs. Rhetoric. The Academy of Management Executive (1987-1989). 3(2): 141-143.

[41] Rosenstein, S. and Wyatt, J. G. 1990. Outside Directors, Board Independence, and Shareholder Wealth. Journal of Financial Economics. 26: 175-92.

[42] Said, R., Zainuddin, Y. H., and Haron, H. 2009. The Relationship Between Corporate Social Responsibility Disclosure and Corporate Governance Characteristics in Malaysian Public Listed Companies. Social Responsibility Journal. 5(2): 212-226.

[43] Salleh, A., and Mustapha, M. 2005. Environmental Reporting Disclosures by Public Listed Companies in Malaysia. The Chartered Secretary Malaysia. May: 12-17.

[44] Saleh, M., Zulkifli, N., and Muhamad, R. 2011. Looking for Evidence of the Relationship Between Corporate Social Responsibility and Corporate Financial Performance in an Emerging Market. Asia-Pacific Journal of Business Administration. 3(2): 165-190.

[45] Shahin, A. and Zairi, M. 2007. Corporate Governance as a Critical Element for Driving Excellence in Corporate Social Responsibility.
International Journal of Quality and Relaibility Management. 24(7): 753-770.

[46] Smith, M., Yahya, K., and Amiruddin, A. M. 2007. Environmental Disclosure and Performance Reporting in Malaysia. Asian Review of Accounting. 15(2): 185-199.

[47] Spitzeck, H. 2009. The Development of Governance Structures for Corporate Responsibility. Corporate Governance. 9(4): 495-505.

[48] Unerman, J. 2000. Methodological Issues-Reflections on Quantification in Corporate Social Reporting Content Analysis. Accounting, Auditing and Accountability Journal. 13(5): 667-681.

[49] Uwuigbe, U. 2011. An Examination of the Relationship between Management Ownership and Corporate Social Responsibility Disclosure: A Study of Selected Firms in Nigeria. Research Journal of Finance and Accounting. 2(6): 23-29.

[50] Yao, S., Wang, J., \& Song, L. 2011. Determinants of social responsibility disclosure by Chinese firms. Discussion Paper 72. China Policy Institute, The University of Nottingham.

[51] Yatim, P., Kent, P., \& Clarkson, P. 2006. Governance Structures, Ethnicity, and Audit Fees of Malaysian Listed Firms. Managerial Auditing Journal. 21(7): 757-782

[52] Zahra, S. A., Neubaum, D. O., and Huse, M. 2000. Entrepreneurship in Medium-Size Companies: Exploring the Effects of Ownership and Governance Systems. Journal of Management. 26(5): 947-976. 